\title{
Literature Study on Community Participation in Community Based Rural Water Supply and Sanitation Programs
}

\author{
Siti Robiah Nurbaiti ${ }^{*}$, and Azis Nur Bambang ${ }^{2}$ \\ ${ }^{1}$ Master Program of Environmental Science, School of Postgraduate Studies, Diponegoro University, Semarang - Indonesia \\ ${ }^{2}$ Fisheries and Marine Science Faculty of Diponegoro University, Semarang - Indonesia
}

\begin{abstract}
Clean water and proper sanitation are basic human needs, existing procurement in the Law of the Republic of Indonesia Number 7 of 2004 on Water Resources and Government Regulation of the Republic of Indonesia Number 16 of 2005 on Development of Water Supply System, which the state guarantees the right of everyone water for basic daily minimum needs to meet the needs of a healthy, productive, and clean life. Norms every society has the right to get clean air to meet basic daily needs. One of the points in the goal of sustainable development goals (SDGs) in the environment sector is the guarantee of the community to achieve universal access to clean water and sanitation. The SDG High Level Panel held in 2012 calls on countries around the world to do so in 2030. Fulfillment of clean air and sanitation in Indonesia is conducted through two sectoral approaches, the first through agencies, or related agencies and the second through a Society. In accordance with its community-based principles, the role itself is a key factor in the success of the program. Therefore, the purpose of this paper is to find out the forms of community participation and the factors that influence participation in communitybased water supply and sanitation programs in the field of literature studies of previous research such as research journals, theses, theses, dissertations and related books This literature study topic.
\end{abstract}

\section{Introduction}

Water is the largest part of the planet. Water is also an important part of life on earth. The amount of water present in the earth, $97.5 \%$ is sea water (salty) and only $2.5 \%$ of fresh water which more than 2 thirds of its parts froze in the form of ice while fresh water that does not freeze only $30 \%$ can be found primarily In soil in the form of groundwater. Of the amount of clean water in the world is only $1 \%$ that can be consumed, and not all can be accessed easily by the community [1].

Clean water and basic sanitation have an important role as an indicator of poverty, especially in efforts to improve public health. The Millennium Development Goals (MDGs) place the guaranteed supply of drinking water and sanitation into the main objective to be achieved by 2015 ie the $7 \mathrm{C}$ target of halving the proportion of households without sustainable access to water resources is for the proportion of households with sustainable access To a viable drinking water source. The achievement of MDGs in Indonesia in 2014, for access to urban drinking water and rural areas reached $68.36 \%$ of the target set by the government of $68.87 \%$, while the proportion of households with sustainable access to basic basic sanitation facilities, urban and rural has reached $61,04 \%$ of the targeted $62.41 \%$ [2].

After the MDGs end in 2015, the member country leaders agreed to continue the noble ideals of MGDs wishing to concentrate on famine and poverty in the world with SDGs (Sustainable Development Goals / SDGs) with one of the points in the goal of sustainable development in the environmental sector To ensure that communities achieve universal access to clean water and sanitation. The High Level Panels of SDGs held in 2012 called on countries around the world including Indonesia to achieve this goal by 2030 . To achieve these objectives there are six targets to be achieved: to create equitable access to drinking water, to create affordable access to sanitation, to increase Water quality by reducing the level of contamination, improving water use efficiency to avoid scarcity, implementing integrated water source management and protecting as well as restoring ecosystems related to water sources including mountains, forests, wetlands, rivers, groundwater and lakes [3].

The availability of clean water and proper sanitation is a basic human need, as contained in the Law of the Republic of Indonesia Number 72004 regarding Water Resources and Government Regulation No. 16 of 2005 on the Development of Water Supply System, that the state guarantees the right of everyone to Get water for basic daily minimum needs to meet the needs of a healthy, productive, and clean life. This means that every community has the right to get clean water to meet basic daily needs.

Clean water in addition to drinking, is also used for most of the day-to-day activities of humans, such as washing, cooking, and others. But in reality, there are still many people who have difficulty obtaining it, causing various problems in society, especially in rural areas. One of the efforts made by the government to overcome this problem is the Community Based Drinking and Sanitation (PAMSIMAS) Program which is a continuation of the WSLIC2 program. In addition,

*Corresponding author:baityjannati14@gmail.com 
many companies also contribute through Corporate Social Responsibility (CSR) as a manifestation of commitment built by the company to contribute to improving the quality of life of the community through various programs such as the provision of clean water and sanitation facilities based on community and direct water distribution to the community which requires them to be done by PT. Exxonmobile [4-5].

In accordance with its community-based principles, the active participation of the community itself is a key factor in the success of the program. Both PAMSIMAS and CSR programs are implementation of Community Development. Ife (1995) suggests that one of the principles of Community Development (CD) is participation. Participation in community development should create an active involvement of all people in the community in the process of community activity [5], where one definition of community participation is community participation in the process of identifying problems and potentials in society, Problems, implementation of problem solving efforts, and community involvement in the process of evaluating the changes

To measure the success of water supply and sanitation program using community development approach, among others by looking at the form of community participation in the program where in the implementation of course influenced by various factors both internal and external. With participation, it is expected that the program will be more sustainable because it is based on the actual basic needs of the local community.

\section{Forms of Community Participation}

According to Ericson in [6], the form of participation given by society in the development stage has several forms that are divided into three stages:

1) Participation in the planning stage (idea planning stage). Participation at the stage has a purpose is the involvement of a person at the stage of preparation of plans and strategies in the preparation of committees and budgets in an activity / project. The community is able to participate by providing suggestions, suggestions, criticisms through meetings;

2) Participation in the implementation stage (implementation stage). Participation at this stage means the involvement of a person at the stage of implementation of a project work. The community here can provide energy, money or material / goods, and ideas as one form of participation in the work; and

3) Participation in utilization. Participation at this stage means the involvement of a person at the stage of utilizing a project after the project is completed. The participation of the community at this stage is in the form of manpower and operating money, as well as maintaining the projects that have been built.

In general there are several forms of participation that can be provided by the community in a development program, namely money participation $[7,8]$, participation of property $[7,8,9]$, labor participation $[7,9]$, skills participation $[7,9]$, participation of ideas $[7,9]$, social participation $[7,9]$, participation in decisionmaking processes [8], and participation of representatives [8]. The explanation can be seen in Table 1.

Table 1. Form of participation

\begin{tabular}{|c|c|}
\hline $\begin{array}{c}\text { Form of } \\
\text { participation }\end{array}$ & \multicolumn{1}{c|}{ Explanation } \\
\hline Money & $\begin{array}{c}\text { A donation of money to facilitate efforts } \\
\text { for the achievement of the needs of the } \\
\text { people who need help. }\end{array}$ \\
\hline Material & $\begin{array}{c}\text { Donations of property, for example: work } \\
\text { tools, tools }\end{array}$ \\
\hline Manpower & $\begin{array}{c}\text { Donations to support the success of the } \\
\text { program }\end{array}$ \\
\hline Skills & $\begin{array}{c}\text { Provide encouragement through skills it } \\
\text { has to other members of the community }\end{array}$ \\
\hline Ideas & $\begin{array}{c}\text { Contribution of ideas, opinions, or } \\
\text { constructive ideas }\end{array}$ \\
\hline Social & $\begin{array}{c}\text { Donation Social, attention as a sign of the } \\
\text { community or a sign of closeness }\end{array}$ \\
\hline $\begin{array}{c}\text { Decision } \\
\text { Making }\end{array}$ & $\begin{array}{c}\text { involved in making decisions related to } \\
\text { common interests }\end{array}$ \\
\hline Representative & $\begin{array}{r}\text { Provide trust / mandate to the } \\
\text { representative sitting in the organization } \\
\text { or committee }\end{array}$ \\
\hline
\end{tabular}

At the time of program planning, the form of community participation is the contribution of the good thoughts in the form of suggestions and suggestions, nevertheless the people who come and remain silent still take part in decision making $[10,11]$. In other research results, people can propose ideas but in some cases the decision is in the hands of the government [12].

The implementation phase is in the form of energy and money, and this usually has been their commitment since the beginning of planning so that the implementation process of the program can run well and not cause adverse impact to the environment and social. For those who can not contribute money, they will contribute energy by taking the time to participate in consecrated work and become a construction worker, and some provide both money and energy. Vita and chika, In addition there are people who donate property or materials in the form of work tools and building materials [11]

After the implementation of the program, the need for community participation in utilizing what has been built and it is very important. People will feel the benefits directly and can improve the quality of their lives so that the results of development into a tangible form. The form of participation after implementation to maintain that has been built is usually a donation of money in the form of contributions $[10,11,12]$. 
The form of community participation given in each stage of water supply and sanitation program can foster a sense of togetherness in realizing an awareness of environmental conditions in the region, a sense of ownership of existing facilities and infrastructure, so as to have a considerable effect on the smoothness and sustainability of the program.

\section{Factors Affecting Community Participation}

From the literature it is found that generally community participation is influenced by two factors, namely internal and external.

1) Internal factors that include individual characteristics that can affect the individual to participate in an activity, namely age, sex, family status, education level, ethnicity, religion, language, occupation, income level, the distance of the house to the location of work or activity And land ownership [13]

2) external factors are all outside parties with an interest and have influence on the program, among others Village managers, community leaders, Local Government, NGOs, third parties (NGOs, Social foundations, Universities) [14]

Individual characteristic factors can affect group activity, individual mobility and financial ability [6]. From several research results indicate that the age of the respondents significantly influence the participation of the community. This means that the high level of community participation is strongly influenced by the age society composition $[10,11,15,16]$. In this case the number of respondents who answered based on the results of questionnaires and interviews is not a representation of the age of the community as a whole at the study site, because in the study only took a representative sample of the family as users of clean water infrastructure.

Gender influences liveliness in discussions, donations and the involvement of physical activities. Male respondents were more active in following activities than women $[10,11,15]$. According to Soedarno et. Al (1992) this can happen because within the social coating system on the basis of this sexuality, the male class has a number of privileges over the women. Thus the tendency is that men's groups will participate more [17].

Educational factors are considered important because through education, one will more easily communicate and interact with others and quickly respond to the development of knowledge and technology. The higher the education, of course, has a broad knowledge of development and the role of the given role [6]. With a high level of education a person has more knowledge in planning activities and more easily filtering outward influences [15]. The level of education affects the liveliness of the discussion. The existence of new information with simple language and practical example becomes an opportunity for people who only have elementary school graduates to find out and get involved, especially if the activities are profitable [10]. The targets of rural water supply and sanitation programs implemented in the villages are poor, thus providing opportunities for lower-level communities to take a more dominant role so that financial capability should not be an obstacle to participation. This can be seen from some people who participate in the water resources management program is a society with a range of income $<$ Rp. 700.000, - [10, 11, 15].

For work is very diverse, but because the program is implemented in the village, it is mostly as laborers and private $[10,11]$. As for ethnicity and religion it is usually related to the status of the community whether as a native or an immigrant $[10,11,15]$.

Research conducted [15] by comparing community participation in two receiving villages of PAMSIMAS receiving Village Hibah Incentives (HIDs) and those not receiving HIDs, it was found that the factors that led to the implementation of participation in HID villages were optimal because of strong community characteristics And influential in every stages of the program so as to form a joint strength to build and target the success of the program PAMSIMAS can be more easily achieved, and the level of participation in the management phase has reached the level of full control (full control).

From the research results, the role of village officials, community leaders, local government, and accompanying teams and NGOs have an effect on the level of community participation. Approaches with attention, attending meetings, providing direction and input, and interacting directly with the community are effective in encouraging people to support the program [10].

Factors - factors above determine the shape and level of community participation that takes place in an activity. The effect that appears at each place is not the same, although it takes place in a nearby area. In addition, the ability of factors to affect each individual is also not the same.

\section{Conclusion}

The form of community participation in the implementation of community-based water supply and sanitation program is in the form of money, thought, energy, material or material contribution, and decision making. Factors affecting community participation are divided into internal factors derived from within the community itself, ie individual characteristics, while external factors are external factors that can encourage or hamper participation, among others the role of village officials, community leaders, local government, NGOs and accompanying teams or facilitator.

\section{Reference}

1. www.pkpu.org [Internet]. Available from: www.pkpu.org

2. Bappenas. Laporan Pencapaian Tujuan Pembangunan Milenium di Indonesia 2014. 
Jakarta; 2015.

3. UNEP \& UNDP. Indicators and Data Mapping to Measure Sustainable Development Goals ( SDGs) Targets (Case of Indonesia 2015). Jakarta; 2015.

4. www.exxonmobil.co.id.

5. Muhdar, Jamaludin, Irwansyah. $\mathrm{J}$ Bisnis dan Pembang. 2014;1 No 1:22-8.

6. Slamet Y. Pembangunan Masyarakat Berwawasan Partisipasi. Surakarta: Sebelas Maret University Press; 1994.

7. Hamijoyo. Pembangunan Masyarakat Berwawasan Partisipas. Yogyakarta: UGM Press; 2007.

8. Holil Soelaiman. Partisipasi Sosial dalam Usaha Kesejahteraan Sosial. Bandung; 1980.

9. Pasaribu, Simanjuntak. Rasa Percaya Diri Sendiri. Salatiga: Pusat Bimbingan Universitas Kristen Satya Wacana; 2005.

10. Ratnasari AV. Partisipasi Masyarakat dalam Program Penyediaan Air Minum dan Sanitasi Berbasis Masyarakat (PAMSIMAS) Di Kabupaten Pekalongan (Studi Kasus Desa Kwayangan Kecamatan Kedungwuni dan Desa Lambenggelun Kecamatan Paninggaran). Universitas Diponegoro. Semarang; 2014.

11. Chaerunnissa C. Jurnal Politika. 2014;5(2).
12. Ratnawati B. Tingkat Partisipasi Masyarakat dalam Pengelolaan Lingkungan melalui Program Penyediaan Air Minum dan Sanitasi berbasis Masyarakat (PAMSIMAS) (Studi Kasus Desa Sodong Kecamatan Wonotunggal dan Desa Mojotengah Kecamatan Reban). Universitas Diponegoro. Semarang; 2012.

13. Cohen, J. and Uphoff N. Rural Development Participation Concept and Measure for Project Design Implementation and Evaluation [Internet]. New York: Cornell University; 1980. Available from:

https://www.researchgate.net/publication/37882394 _Rural_development_participation_concepts_and measures_for_project_design_implementation_and evaluation

14. Sunarti. Jurnal Tata Loka. Semarang; 2003;

15. Afriadi T, Wahyono H. 2012;8(4):341-8.

16. A. Tenriawaruwaty. Partisipasi Masyarakat dalam Pengelolaan Sumberdaya Air Secara Berkelanjutan di Kabupaten Bulukumba. Universitas Hasanuddin. Makasar; 2013.

17. Suciati. Partisipasi Masyrakat dalam Penyusunan Rencana Umum Tata Ruang Kota Pati. Universitas Diponegoro. Semarang; 2006. 